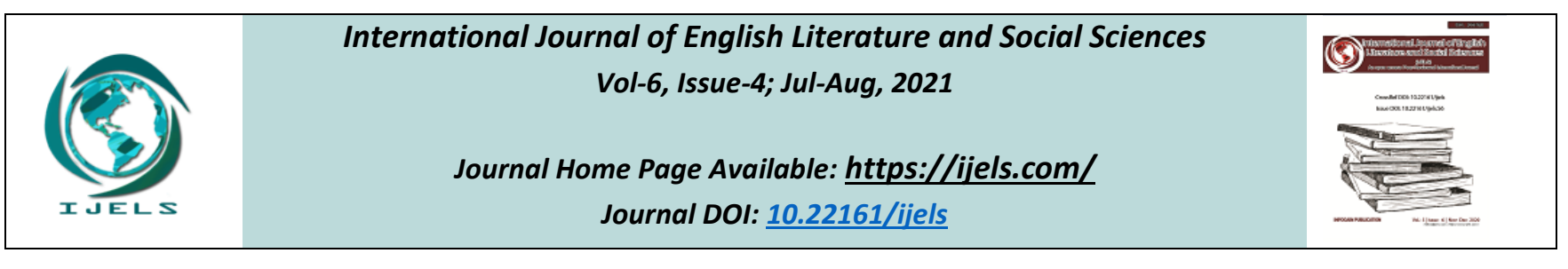

Peer-Reviewed Journal

\title{
Kafka's poetics of the Grotesque: Questioning the Animal in Kafka's oeuvre
}

Ratul Nandi

Assistant Professor, Siliguri College, West Bengal

Received: 16 Jul 2021; Received in revised form: 13 Aug 2021; Accepted: 20 Aug 2021; Available online: 27 Aug 2021

(c)2021 The Author(s). Published by Infogain Publication. This is an open access article under the CC BY license

(https://creativecommons.org/licenses/by/4.0/).

\begin{abstract}
Kafka's works abounds in animal figures that occupy an ontological liminality. They are nether truly animals nor exactly humans but always pushes towards a zone where the categories become immaterial. In addition to causing literary disorientation, these figures serve to offer stringent critique of our anthropocentric idealism that sustains our species identity. By carefully examining the dialectical interplay between knowledge and ignorance, the articles attempt to situate Kafka's non-human figures as expressing a deeper connection between concepts of animality and idea of literature.
\end{abstract}

Keywords — liminal, Kafkaesque, ontological, nonhuman.

Kafka's work has always troubled the boundaries between the human and the non-human. What we have always famously called the "Kafkaesque" is more than just a style of expression, it is the very grammar of his writingwhether one reads his letters, journals or his literary works - that has contributed towards creating a constant ontological unrest and anxiety at the frontier of our species identity. Ted Geier in his recent work on Kafka has said something very interesting about how Kafka's nonhuman animal characters offer critique of anthropocentrism that in a way prepares us for what we now call 'animal studies':

"Kafka anticipated Animal Studies critiques of anthropocentrism but also worked through this concept in attempts to express the nonhuman despite human forms of expression and thought. Literature has always troubled such boundaries through "strange" narrative strategies, and recent work in Animal Studies and the "Nonhuman Turn" owes much to Kafkan form. His formal ambiguities, perhaps they are even failures, work to undo the violence of the human that persists even where humanism has already been rejected."

Although the figure of the animal has not directly entered Kafka's texts, there are footprints of animals all over his body his works. But his animal figures are neither completely human nor completely animals. It is this grotesque idea that constantly occupies his peculiar nonhuman frame: nonhuman and cross-human creatures appear in all his longer stories and about half his shorter ones. The grotesque grammar of his non-human portrayals evidently has a deeper implication than one can easily anticipate. They are not the allegorical props used to comment something about the humans. Rather, his strange disorienting style makes room for the type of grotesque creatures who resist all conceptual classification. Animality for him is 'internal'. His belief is that man's suppressed animality needs a proper outlet. Kafka's diaries and letters are full of bizarre referees to this animal that lives within man. Kafka's close friend and biographer Max Brod opens our eyes to Kafka's strange view of animals he held during his lifetime as when he once called the animals as "hacking cough emanating from one's throat". Kafka's idea of internal animality is a heap of dark repressed human desires that are never given a proper outlet. Thus, for Kafka, animality is man's first nature and is indispensable to his entire existence. In other words, as Christina Gerhardt correctly comments, "one cannot do without animals, as Kafka, too, affirms in his animal stories, since as totems animals at once express and suppress these incestuous desires" (162). 
It this figure of the animal within that sustains Kafka's unique non-human frame whether one sees underground creature in The Burroughs, the unnamed dog in Investigations of $\boldsymbol{a}$ Dog, the humanised mouse in Josephine, the Singer or the Mouse Folk. But more precisely than any of these presentations, Kafka leaves us with two particular animal figures in Metamorphosis and in A Report To Academy respectively that best explains his own method of non-human writing. In Metamorphosis, Kafka presents us with an unforgettable human-animal hybrid figure. Once again, with the figure Gregor Sama, Kafka helps us grasp what it is to be re-possessed by the animal other. In the story of Gregor transformation from an ordinary salesman to an insect, the focus is always on the nature of metamorphosis the character undergoes. The first few lines of the novel narrate this transformation in a very matter -of-fact manner as if there is nothing surprising about it:

One morning, as Gregor Samsa waking up from anxious dreams, he discovered that in bed he had been changed into a monstrous verminous bug. He lay on his armourhard back and saw, as he lifted his head up a little, his brown, arched abdomen divided up into rigid brow-like sections. From this height the blanket, just about ready to slide off completely, could hardly stay in place. His numerous legs, pitifully thin in comparison to the rest of his circumference, flickered helplessly before his eyes. (The Metamorphosis, translation by Ian Johston,1915).

The rest of the story describes Gregor's gradual coming to terms with his new body. Although he initially found his transformation repulsive, slowly he begins to open himself up to the new bodily affectivity that his changed appearance induced. It is good to remember that we crucially meet Gregor in the novel when is under transformation: he has not yet entirely transformed into a giant bug, nether is he the same Gregor Samsa he used to be like. Kafka by deliberately directs our attention to Gregor's in-between state of existence which belons neither to human nor to animal in particular. The political inflection of this between figure has the effect of undermining the idea of anthropocentric dualism that informs out taken-for-granted idea of speciesism. Instead of coming up with either a human or an animal figure, Kafka chooses to complicate the knowledge of species paradigm by giving us both human and animal hybrid figure. Thus, Kafka anticipates animal studies objective of challenging of speciesism long before it became an academic discipline.

If Kafka's Metamorphosis leaves us with a human transforming into an animal, his short novella A Report to an Academy gives us the story about an ape animal who has been transformed into a respectable member of academy. He is captured from ape family and brought into the mainland of Europe where upon receiving the best of modern education he gradually develops as a human member. When finally questioned by the academy to reveal his animal past, Red Peter fails in his task as his modern education leaves no room for him to retrieve his lost animality. In Kafka's story, Red Peter has learned to live and to speak as a human, but this ability has distanced him from expressing his innermost truths of his original animality. Kafka's irony is very much apparent when Red Peter confirms that his release from his ape life should not be conflated with "freedom". As he seems to indicate, "I fear that perhaps you do not quite understand what Iman by 'way out.' I use the expression in its fullest and most popular sense. I deliberately do not use the word "freedom"' (Kafka, 198).Kafka's text offers a criticism of the way we valorise knowledge brought through the system of languageand spurn stupidity in the form of ignorance by virtue of lack of such signifying systems. The text of Kafka seems to pose the question - Knowledge at what cost?

Kafka ironically mounts his critique against the Enlightenment values which considers human knowledge to be a redemptive virtue of mankind. Like Nietzsche, who denounced the all too human values and embraced the animal, Kafka believed that the knowledge is frail medium that forever fails to explain the human. But unlike Nietzsche, who believed that only way humanity achieve redemption is by freeing themselves from grip of knowledge, Kafka does not believe that humanity can easily slip backwards its animal past. This is one crucial issue where Kafka contradicts Nietzsche. Like Red Peter who can never go back to animal past, humans also cannot straightforwardly choose to undo their trappings of reason and the garb of culture. However, they can certainly retain the trace of their lost animality by occupying an inbetween state of being which is neither properly human nor completely animal.

In A Report to an Academy this takes us the form of an interesting dialectic between language and silence. Language gives Red Peter the power of expression to articulate his feeling, to voice his belief. But at the same moment it turns out to be a repressive mechanism since it does not allow him to detail the accounts of his prelinguistic ape past. Thus, his silence speaks more truth than his language. Thus, the only way Red Peter could express his animal being is by sounding gibberish and paradoxical.

Kafka's unique understanding of the grotesque and insipid animality is consistent with his vision of literature. In other 
words, he considers this secret experience of animality is something that can only be understood through literary experience. As tells his friend Max Brod that a "writer is the scapegoat of mankind". Like all his enigmatic expressions this one too remains resistant to easy interpretation. However, it does make sense when one considers the intimate link Kafka is trying to forge between his experience of suppressed animality and his experience of literature. This does not simply tell us that how literature gives us a glimpse into inarticulable animality that remains submerged in the writer. Rather, the point is to demonstrate how our very experience of literature is possible only because language forever fails to capture the true essence of reality. There is an essential experience of animal sacrifice at the beginning of writing. This takes us to the very essence of our language and idea of signification. Whereas in our everyday understanding the language perfectly functions by corresponding to things in the extralinguistic world, the language of literature does not correspond to any external referents outside language of literature reminds us of the ultimate absence of meaning in the language itself. This is the very animalistic experience that literature first and foremost makes us realize. Hence Kafka, calls the writer the very "scapegoat of humanity" because only he has the power to re-enact the ultimate animal sacrifice the lies at the root of humanity. This is the reason he says that it is only the writer who "makes it possible for men to enjoy sin without guilt, almost without guilt" (Kafka 1979, 295).

Kafka's works thus brings together a very singular nonhuman frame. His animals hardly behave like those of real animals. Complex as they are, Kafka's animal stories do not come with any ready-made hermeneutical elucidation. They seem always to point towards a liminal zone that contest and problematize any clear-cut distinction between animal and human.His method is nuanced and not definitive Aglance through Kafka's work in general is convincing enough to his readers how he carefully heuses animal figures and tropes that serve to 'defamiliarize', to use Viktor Sholovsky's term, anypre-existing sense of animals we already have. His animals are uncanny liminal figures that offera strong jolt to our logic of sense.

\section{REFERENCES}

[1] Derrida, Jacques. The Beast and the Sovereign. Trans. Geoffrey Bennington. Chicago: U of Chicago Press, ,2009

[2] Geier, Ted. Kafka's Nonhuman Form.Troubling the Boundaries of the Kafkaesque.Palgrave Macmillan,2016.

[3] Kafka, Franz. The Complete Stories. New York: Schocken Books, 1971
[4] Kafka, Franz. 'The Burrow." Trans.Willa Muir and Edwin Muir. The Penguin Complete Short Stories of Franz Kafka. Ed. Nahum N. Glatzer. Harmondsworth: Penguin,1983.

[5] Koelb, Clayton. "Kafka Imagines his Readers: The Rhetoric of 'Josefine die Sa«ngerin'and 'Der Bau'.' Ed. Harold Bloom. New York: Infobase, 2010

[6] Nietzsche, Friedrich. Beyond Good and Evil. Trans.Walter Kaufmann. Basic Writings of Nietzsche. New York: Modern Library, 2000 